\title{
Polymorphism of Bismuth Sesquioxide. I. Pure $\mathrm{Bi}_{2} \mathrm{O}_{3}$
}

\author{
Ernest M. Levin and Robert S. Roth
}

\author{
(December 3, 1963)
}

\begin{abstract}
Stability relationships of the four polymorphs of bismuth oxide have been determined by means of DTA and high-temperature x-ray studies. The stable low-temperature monoclinic form transforms to the stable cubic form at $730+5{ }^{\circ} \mathrm{C}$, which then melts at $825+5{ }^{\circ} \mathrm{C}$. By controlled cooling, the metastable tetragonal phase and/or the metastable body-centered cubic (b.c.c.) phase appear at about $645^{\circ} \mathrm{C}$. Whereas b.c.c. can be preserved to room temperature, tetragonal will transform to monoclinic between 550 and $500{ }^{\circ} \mathrm{C}$. Tetragonal $\mathrm{Bi}_{2} \mathrm{O}_{3}$, however, is easily prepared by decomposing bismutite $\left(\mathrm{Bi}_{2} \mathrm{O}_{3} \cdot \mathrm{CO}_{2}\right)$ at $400{ }^{\circ} \mathrm{C}$ for several hours. The greatest transition expansion occurs at the monoclinic to cubic inversion, and cubic $\mathrm{Bi}_{2} \mathrm{O}_{3}$ shows the greatest coefficient of volume expansion. With exposure to air, $\mathrm{Bi}_{2} \mathrm{O}_{3}$ carbonates and partially transforms to bismutite and an unknown phase.
\end{abstract}

\section{Introduction}

Bismuth oxide is assuming an increasing importance in the ceramic field, particularly in the glass and electronics industries. A literature survey of the polymorphism of $\mathrm{Bi}_{2} \mathrm{O}_{3}$, in connection with phase studies of the systems $\mathrm{Bi}_{2} \mathrm{O}_{3}-\mathrm{B}_{2} \mathrm{O}_{3}[1]^{1}$ and $\mathrm{Bi}_{2} \mathrm{O}_{3}-$ $\mathrm{Nb}_{2} \mathrm{O}_{5}[2]$, revealed unexplained inconsistencies in the data and no unequivocal interpretation. Furthermore, it was realized that a conclusive study of the polymorphic relationships would involve an identification of phases at temperature.

A number of investigators [3-10] have reported on temperatures of transitions and phase changes in $\mathrm{Bi}_{2} \mathrm{O}_{3}$. Schumb and Rittner [6] have reviewed the work prior to 1943 . Table 1 summarizes the literature data through the work of the present authors, and includes, when given, methods of preparation and study, stable and unstable polymorphs, and temperatures of transitions.

It can be seen from the table that both pure and impure forms of $\mathrm{Bi}_{2} \mathrm{O}_{3}$ have been reported, with disagreement among investigators both as regards the identity and the stability of the pure phases. The essential conclusions which may be drawn from the previously reported data, as given in table 1 , are as follows:

(1) All investigators agree that monoclinic (Mon), pseudo-orthorhombic, $\left(\alpha-\mathrm{Bi}_{2} \mathrm{O}_{3}\right)$ is the stable low temperature form.

(2) Schumb and Rittner believe that the tetragonal (Tet), or pseudocubic form $\left(\beta-\mathrm{Bi}_{2} \mathrm{O}_{3}\right)$ is stable above $710^{\circ} \mathrm{C}$. Sillén suggested that this form might be simple cubic at higher temperatures. He based his hypothesis, in part, on analogy with cubic (C) $\mathrm{As}_{2} \mathrm{O}_{3}$ and $\mathrm{Sb}_{2} \mathrm{O}_{3}$.

1 Figures in brackets indicate the literature references at the end of this paper.
(3) Schumb and Rittner discovered a b.c.c. phase $\left(\gamma-\mathrm{Bi}_{2} \mathrm{O}_{3}\right)$ representing a metastable form of $\mathrm{Bi}_{2} \mathrm{O}_{3}$. The finding was confirmed later by Aurivillius and Sillén, who agreed that the unit cell probably contained $\mathrm{Bi}_{26} \mathrm{O}_{39}$.

(4) Gattow and Schröder, from the results of high-temperature x-ray, differential thermal analysis, and linear thermal expansion studies have found only two polymorphs of $\mathrm{Bi}_{2} \mathrm{O}_{3}$, namely the low temperature Mon form which transforms reversibly to a high temperature, face-centered cubic form, designated $\delta-\mathrm{Bi}_{2} \mathrm{O}_{3}$

(5) A number of investigators have reported an impure b.c.c. phase, formed by contamination with porcelain, $\mathrm{Si}, \mathrm{Fe}, \mathrm{Al}$, and other impurities. Sillén suggested the ideal formula type $\mathrm{Me}_{2} \mathrm{Bi}_{24} \mathrm{O}_{40}$.

(6) Gattow and Schröder ${ }^{2}$ propose the designation $\delta^{*}, \beta^{*}, \gamma^{*}$ for the impurity forms of C-, Tet-, and b.c.c. $\mathrm{Bi}_{2} \mathrm{O}_{3}$, respectively.

(7) Previous investigators, usually using a cooling curve method, have reported transition temperatures between 700 and $717{ }^{\circ} \mathrm{C}$. Liquidus temperatures vary from 817 to $825^{\circ} \mathrm{C}$.

The objective of this work (part I) was to clarify the polymorphic relationships of pure $\mathrm{Bi}_{2} \mathrm{O}_{3}$. This could best be accomplished by the method of hightemperature x-ray diffractometry, which avoids the problem of nonquenchable phases. The study was enlarged (part II) to include the effect of oxide additions on the polymorphism of $\mathrm{Bi}_{2} \mathrm{O}_{3}$, when a modification of the $\mathrm{x}$-ray furnace permitted the determination of solidus temperatures and even, under favorable conditions, of liquidus temperatures. It was expected that the latter study would provide information on the impure forms.

${ }_{2}^{2}$ Gattow and Schröder [10] report a metastable bismuth oxide phase, $\mathrm{Bi}_{3} \mathrm{O}_{5}$, formed under oxidizing conditions and very similar in structure to Tet, $\boldsymbol{\beta}-\mathrm{Bi}_{2} \mathrm{O}_{3}$; however, no identifying characteristics other than chemical analysis are given. Moreover, it transforms to $\boldsymbol{B}-\mathrm{Bi}_{2} \mathrm{O}_{3}$ in about 3 months at $20^{\circ} \mathrm{C}$, or more rapidly at $470 \pm 50^{\circ} \mathrm{C}$, or in a partial vacuum. 
TABLE 1. Literature summary on polymorphism of $\mathrm{Bi}_{2} \mathrm{O}_{3}$

\begin{tabular}{|c|c|c|c|c|c|c|}
\hline Investigator & Form & Method of preparation & Notes & Method of study & $\begin{array}{l}\text { Transition } \\
\text { temp. }\end{array}$ & $\begin{array}{l}\text { Melting } \\
\text { temp. }\end{array}$ \\
\hline Guertler (1903) [3] & & $\begin{array}{l}\text { From basic nitrate in porcelain } \\
\text { crucible. }\end{array}$ & (Contains $1.3 \%$ silic acid) & $\begin{array}{l}\text { Cooling curve. } \\
\text { Heating curve. } \\
\text { Cooling curve. }\end{array}$ & $\begin{array}{l}704 \pm 1{ }^{\circ} \mathrm{C} \\
705 \pm 1{ }^{\circ} \mathrm{C}\end{array}$ & $\begin{array}{l}820 \pm 2^{\circ} \mathrm{C} \\
825 \pm 5^{\circ} \\
860^{\circ}\end{array}$ \\
\hline Belladen (1922) [4] & & Calcination of basic nitrate. & & Cooling curve. & & $817^{\circ}$ \\
\hline Sillén (1937) [5] & $\begin{array}{l}\alpha-\mathrm{Bi}_{2} \mathrm{O}_{3} \text { (Mon) } \\
\beta-\mathrm{Bi}_{2} \mathrm{O}_{3} \text { (Tet) } \\
\text { b. c. c. } \\
\text { Cubic } \mathrm{Bi}_{2} \mathrm{O}_{3}\end{array}$ & $\begin{array}{l}\mathrm{Bi}\left(\mathrm{NO}_{3}\right)_{3}(\mathrm{aq})+\mathrm{KOH}(\mathrm{aq}) \text {. } \\
\mathrm{Condensation} \mathrm{of} \mathrm{bismuth} \mathrm{vapor} \\
\text { from graphite furnace, in } \mathrm{O}_{2} \\
\text { stream. } \\
\text { Fused in porcelain at } 900^{\circ} \mathrm{C} \text { for } \\
5 \text { min or with } \mathrm{Al}_{2} \mathrm{O}_{3} \text { or } \mathrm{Fe}_{2} \mathrm{O}_{3} \text {. } \\
\text { Fused in porcelain at } 900{ }^{\circ} \mathrm{C} \text { for } \\
20 \text { min. }\end{array}$ & $\begin{array}{l}\text { Stable low-temp. form. } \\
\text { May be cubic at higher tem- } \\
\text { peratures. } \\
a=10.93 \\
c=5.62 \mathrm{kx} \text {. } \\
\text { Suggested formula type: } \\
\quad \mathrm{Me}_{2} \mathrm{Bi}_{24} \mathrm{O}_{40} \text {. } \\
a=10.08 \mathrm{kx} \\
\text { Contaminated with silicon, } \\
a=5.525 \mathrm{kx} \text {. }\end{array}$ & & & \\
\hline$\underset{(1943)[6]}{\text { Schumb and Rittner }}$ & $\begin{array}{l}\alpha-\mathrm{Bi}_{2} \mathrm{O}_{3} \text { (Mon) } \\
\beta-\mathrm{Bi}_{2} \mathrm{O}_{3} \text { (Tet) } \\
\gamma-\mathrm{Bi}_{2} \mathrm{O}_{3} \\
\text { (b. c. c.) } \\
\text { b. c. c. } \\
\text { Cubic } \mathrm{Bi}_{2} \mathrm{O}_{3}\end{array}$ & $\begin{array}{l}\text { Purification of } \mathrm{C} . \mathrm{P} . \mathrm{Bi}_{2} \mathrm{O}_{3} \text { by } \\
\text { heating at } 750^{\circ} \mathrm{C} \text { and leaching. } \\
\text { Are between graphite electrode } \\
\text { and molten bismuth in } \mathrm{O}_{2} \\
\text { stream. } \\
\text { Controlled cooling of } \beta-\mathrm{Bi}_{2} \mathrm{O}_{3} \text { from } \\
750-800^{\circ} \mathrm{C} \text { in } \mathrm{Pt} \text { crucible. } \\
\text { Fusion }\left(875{ }^{\circ} \mathrm{C}\right) \text { of } \mathrm{Bi}_{2} \mathrm{O}_{3} \text { in por- } \\
\text { celain and with } \mathrm{SiO}_{2} . \\
\text { Fusion }\left(875^{\circ} \mathrm{C}\right) \text { of } \mathrm{Bi}_{2} \mathrm{O}_{3} \text { in por- } \\
\text { celain or silica crucible at } 875^{\circ} \\
\text { and water quenching. }\end{array}$ & $\begin{array}{l}99.99 \pm 0.06 \% \mathrm{Bi}_{2} \mathrm{O}_{3} . \text { Stable be- } \\
\text { low } 700{ }^{\circ} \mathrm{C} . \\
99.8 \pm 0.2 \% \mathrm{Bi}_{2} \mathrm{O}_{3} \text {. Stable above } \\
710^{\circ} . \\
a=10.93 \\
c=5.63 \mathrm{kx} \text {. } \\
\text { Metastable; probably } \mathrm{Bi}_{26} \mathrm{O}_{39} . \\
a=10.245 \mathrm{kx} \text {. } \\
\text { Impure phase: } a=10.090 \mathrm{kx} \text {. } \\
\text { Impure phase: } a=5.525 \mathrm{kx} \text {. }\end{array}$ & $\begin{array}{l}\text { X-ray examination } \\
\text { of rapidly cooled } \\
\text { Sample }\end{array}$ & $710^{\circ}$ & \\
\hline $\begin{array}{l}\text { Aurivillius and Sillén } \\
\text { (1945) [7]. }\end{array}$ & $\gamma-\mathrm{Bi}_{2} \mathrm{O}_{3}$ (b. c. c.) & $\begin{array}{l}\text { Not given. } \\
\text { Same as Schumb and Rittner } \\
(1943) \text {. }\end{array}$ & $\begin{array}{l}\text { Stated to be pure } \mathrm{Bi}_{2} \mathrm{O}_{3} \text {. } \\
\text { Probably } \mathrm{Bi}_{26} \mathrm{O}_{39} \text {. } \\
a=10.243 \mathrm{kx} \text {. }\end{array}$ & $\begin{array}{l}\text { Cooling curve of } \\
\text { a large quantity } \\
\text { in Pt crucible. }\end{array}$ & $\approx 700^{\circ}$ & \\
\hline $\begin{array}{l}\text { Royen and Swars (1957) } \\
\text { [8]. }\end{array}$ & $\beta-\mathrm{Bi}_{2} \mathrm{O}_{3}$ (Tet) & $\begin{array}{l}\text { Quenched molten } \mathrm{Bi}_{2} \mathrm{O}_{3} \text { from } \\
\text { " } 850^{\circ} \text { or perhaps } 920^{\circ} \mathrm{C} \text { ". }\end{array}$ & $\begin{array}{l}\alpha-\mathrm{Bi}_{2} \mathrm{O}_{3} \text { may also be present } \\
\text { in minor amt. }\end{array}$ & & & \\
\hline $\begin{array}{l}\text { Belayev and Smolay- } \\
\text { nenov (1962) [9]. }\end{array}$ & & $\mathrm{Bi}_{2} \mathrm{O}_{3}$ calcined at $500^{\circ} \mathrm{C} / 1-1.5 \mathrm{hr}$. & & $\begin{array}{l}\text { Visual poly- } \\
\text { thermal. }\end{array}$ & $704^{\circ}$ & $819^{\circ}$ \\
\hline $\begin{array}{l}\text { Gattow and Schröder } \\
\text { (1962) [10]. }\end{array}$ & $\begin{array}{l}\alpha-\mathrm{Bi}_{2} \mathrm{O}_{3} \text { (Mon) } \\
\delta-\mathrm{Bi}_{2} \mathrm{O}_{3} \text { (Cubic) } \\
\delta^{*}-\mathrm{Bi}_{2} \mathrm{O}_{3} \\
\beta^{*}-\mathrm{Bi}_{2} \mathrm{O}_{3} \\
\gamma^{*}-\mathrm{Bi}_{2} \mathrm{O}_{3}\end{array}$ & Not given. & $\begin{array}{l}100.0_{0} \pm 0.10 \% \mathrm{Bi}_{2} \mathrm{O}_{3} \text {. Stable low- } \\
\text { temp. form. } \\
\text { Stable high-temp. form. } \\
a=5.66 \pm 0.008 \text { A (at } 750{ }^{\circ} \mathrm{C} \text { ). } \\
\text { Cubic impurity form. } .^{\mathrm{s}} \\
\text { Tetragonal impurity form. } \mathrm{b} \\
\text { Body-centered cubic impurity } \\
\text { form. }\end{array}$ & $\begin{array}{l}\text { DTA and high- } \\
\text { temp. } x \text { ray. } \\
\text { High-temp. X ray. } \\
\text { X ray. } \\
\text { X ray. } \\
\text { X ray. }\end{array}$ & $717 \pm 7^{\circ} \mathrm{C}$ & $824 \pm 2{ }^{\circ} \mathrm{C}$ \\
\hline $\begin{array}{l}\text { Levin and Roth (pres- } \\
\text { ent work)d }\end{array}$ & $\begin{array}{l}\text { Mon } \mathrm{Bi}_{2} \mathrm{O}_{3} \\
\text { Cubic } \mathrm{Bi}_{2} \mathrm{O}_{3} \\
\text { Tet } \mathrm{Bi}_{2} \mathrm{O}_{3}{ }^{\ominus}\end{array}$ & $\begin{array}{l}\text { Commercial "Spec. pure" and } \\
\text { ACS Grades. }\end{array}$ & $\begin{array}{l}\text { Stable low-temp. form. } \\
\text { Stable high-temp. form. } a= \\
5.66 \AA \text { (at } 750^{\circ} \mathrm{C} \text { ). } \\
\text { Metastable; formed from } \\
\text { super-cooling Cubic } \mathrm{Bi}_{2} \mathrm{O}_{3} . \\
a=10.93 \AA \\
c=5.63 \AA \\
\text { Metastable; formed from } \\
\text { supercooling cubic } \mathrm{Bi}_{2} \mathrm{O}_{3} \text {. } \\
\text { Anion impurities may be } \\
\text { important. } \\
a=10.268 \AA \text {. }\end{array}$ & $\begin{array}{l}\text { DTA and high- } \\
\text { temp. x ray. } \\
\text { High-temp. x ray. } \\
\text { DTA and high- } \\
\text { temp. x ray. } \\
\text { High-temp. x ray. }\end{array}$ & $730 \pm 5^{\circ} \mathrm{C}$ & $825 \pm 5^{\circ} \mathrm{C}$ \\
\hline
\end{tabular}

a Obtained by fast quenching of molten bismuth oxide mixtures heated at 800 to $1000{ }^{\circ} \mathrm{C}$ for 15 to 60 min. $\mathrm{Bi}_{2} \mathrm{O}_{3}$ mixed with: $\mathrm{As}_{2} \mathrm{O}_{3}, \mathrm{Sb}_{2} \mathrm{O}_{3}, \mathrm{La}_{2} \mathrm{O}_{3}, \mathrm{Nd}_{2} \mathrm{O}_{3}$, $\mathrm{Cr}_{2} \mathrm{O}_{3}, \mathrm{SiO}_{2}, \mathrm{SnO}_{2}, \mathrm{TiO}_{2}, \mathrm{~V}_{2} \mathrm{O}_{5}, \mathrm{Nb}_{2} \mathrm{O}_{5}$, Ta $\mathrm{Ta}_{2} \mathrm{O}_{5}$, W $\mathrm{WO}_{3}$. The same phase was obtained from aqueous solution in the system $\mathrm{Bi}_{2} \mathrm{O}_{3}-\mathrm{MoO}_{3}$. b Obtained under certain conditions with mixtures of $\mathrm{Bi}_{2} \mathrm{O}_{3}$ and: $\mathrm{Al}_{2} \mathrm{O}_{3}$ $\mathrm{Ga}_{2} \mathrm{O}_{3}, \mathrm{In}_{2} \mathrm{O}_{3}, \mathrm{Y}_{2} \mathrm{O}_{3}, \mathrm{Tl}_{2} \mathrm{O}_{3}, \mathrm{Fe}_{2} \mathrm{O}_{3}, \mathrm{Cr}_{2} \mathrm{O}_{3}, \mathrm{PbO}_{2}, \mathrm{MnO}_{2}, \mathrm{CeO}_{2}, \mathrm{ZrO}_{2}$, ThO $\mathrm{Th}_{2}$. c Sillén's body-centered cubic (b. c. c.) type. Impurity oxides not listed.

d See also [1, 2].
e Pure tetragonal $\mathrm{Bi}_{2} \mathrm{O}_{3}$ at room temperature can be obtained easily by heating $\mathrm{Bi}_{2} \mathrm{O}_{3} \cdot \mathrm{CO}_{2}$ (bismutite) at about $400^{\circ} \mathrm{C}$ for 2 to $16 \mathrm{hr}$.

$\mathrm{f}$ A related b. c. c. form is either stable or metastable depending on the cation impurity (discussed in part II):

\section{Starting Materials}

Two commercially available grades of bismuth oxide were used. One sample was of reported spectrographic purity; the other sample was certified reagent grade (ACS). The results of a qualitative spectrochemical analysis by the Analytical and Inorganic Chemistry Division of the National Bureau of Standards showed that the reagent grade sample contained iron and silicon $(0.01$ to $0.001 \%)$ in significantly higher concentrations than the spectrographic grade (less than $0.001 \%$ ). Minor differences between the two samples were observed for a number of other elements ( $\mathrm{Ag}, \mathrm{Al}, \mathrm{Ca}, \mathrm{Cr}, \mathrm{Cu}, \mathrm{Mg}, \mathrm{Mn}, \mathrm{Na}$, $\mathrm{Ni}$, and $\mathrm{Pb}$ ), which were each estimated to be present at less than 10 ppm metal in $\mathrm{Bi}_{2} \mathrm{O}_{3}$.

The following commercially available compounds were used for studying decomposition effects on the polymorphism of $\mathrm{Bi}_{2} \mathrm{O}_{3}$ : bismutite $\left(\mathrm{Bi}_{2} \mathrm{O}_{3} \cdot \mathrm{CO}_{2}\right)$, bismuth hydroxide, bismuth nitrate $\left(\mathrm{Bi}\left(\mathrm{NO}_{3}\right)_{3} .5 \mathrm{H}_{2} \mathrm{O}\right)$, bismuth subnitrate, bismuth subgallate, and bismuth subsalicylate. 


\section{Apparatus and Method}

Polymorphic relationships in $\mathrm{Bi}_{2} \mathrm{O}_{3}$ were first deduced from differential thermal analyses of approximately $0.3 \mathrm{~g}$ samples. A few experiments on larger samples (approximately $3 \mathrm{~g}$ ) gave no significant differences. The deduced relationships were then confirmed with the aid of the high-temperature x-ray diffractometer furnace. The diffraction data were obtained with a modification of the diffractometer furnace described by Mauer and Bolz [11]. The essential feature of the modification [12] involved a platinum sample holder to which the powdered samples could be made to adhere by using a thin smear of petroleum jelly. The petroleum jelly volatilizes at a low temperature, leaving the sample adhered to the surface.

It may be noted that the standard quenching technique was of limited value in this study, because the high-temperature form of $\mathrm{Bi}_{2} \mathrm{O}_{3}$ could not be quenched. However, in experiments dealing with the preservation at room temperature of the Tet and b.c.c. metastable phases a small quench furnace of low heat capacity was used. The furnace enabled one to control the cooling rate between two temperatures prior to quenching.

\section{Results and Discussion}

\subsection{DTA and High-Temperature X-Ray Results}

The results of differential thermal analyses of small samples $(0.3 \mathrm{~g})$ are summarized in figure 1 . Phase identification was verified by comparison with the results obtained from the high-temperature $x$-ray diffraction experiments, also shown in figure 1.

The basic phase equilibrium relationships are revealed. At $730 \pm 5{ }^{\circ} \mathrm{C}$, the low temperature Mon form transforms to cubic $\mathrm{Bi}_{2} \mathrm{O}_{3}$ (C) ${ }^{3}$ which remains stable up to the melting point, $825 \pm 5{ }^{\circ} \mathrm{C}$. If the sample is not heated above about $745{ }^{\circ} \mathrm{C}$ (see hightemperature $\mathrm{x}$-ray results), or is heated very rapidly to higher temperatures, then, on cooling, inversion to the Mon form takes place at $700{ }^{\circ} \mathrm{C}$. If some of the Mon form persists above the transition, it will nucleate the inversion, on cooling.

If the $\mathrm{C}$ form is heated above about $775{ }^{\circ} \mathrm{C}$, considerable supercooling of the $\mathrm{C}$ phase occurs, and tetragonal $\mathrm{Bi}_{2} \mathrm{O}_{3}$ forms at 650 to $645{ }^{\circ} \mathrm{C}$. The Tet phase formed in this manner cannot be preserved to room temperature but transforms to the Mon phase at temperatures varying between 550 and $450{ }^{\circ} \mathrm{C}$. If, however, the Tet phase is heated, conversion to the cubic form occurs between 660 and $670{ }^{\circ} \mathrm{C}$.

Data from the high-temperature $\mathrm{x}$-ray experiments revealed the b.c.c. phase in addition to the Tet phase. The b.c.c. phase appeared at a temperature slightly below that at which the Tet phase formed, and on reheating, the b.c.c. to $\mathrm{C}$ transition occurred slightly below that of the Tet to C transition. Once formed the b.c.c. phase could be pre-

3 The x-ray diffraction powder data fit a face-centered cubic cell. Sillén has interpreted the cubic phase as being simple cubic, whereas Gattow and Schröder [10] consider the symmetry to be face-centered cubic.

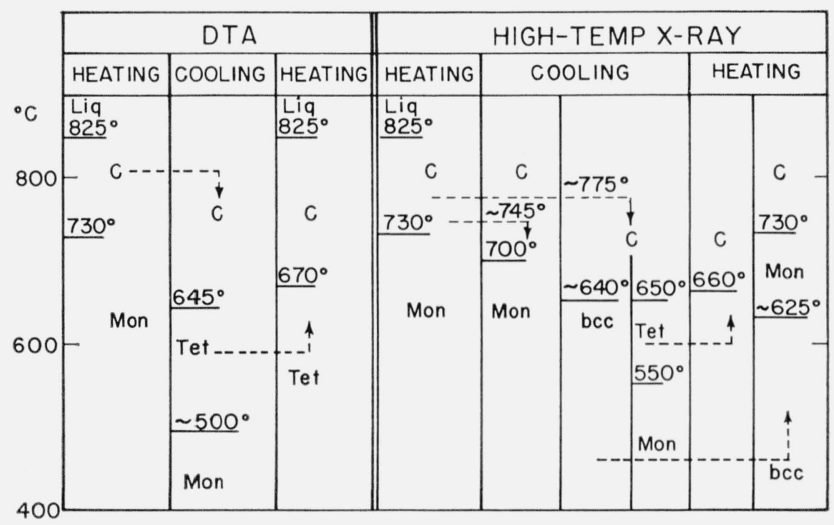

Figure 1. Schematic representation of results of differential thermal analysis (DTA) and high-temperature $x$-ray experiments on $\mathrm{Bi}_{2} \mathrm{O}_{3}$.

Dashed arrows indicate changes in direction of the heating and cooling schedule. Polymorphs: Mon-monoclinic, C-cubic, Tet-tetragonal, b.c.c.-bodycentered cubic.

served to room temperature by "furnace cooling." Slow heating of the b.c.c. phase from room temperature yielded the stable Mon phase at about $625{ }^{\circ} \mathrm{C}$.

A weight-loss determination on $0.3 \mathrm{~g}$ of the ACS grade $\mathrm{Bi}_{2} \mathrm{O}_{3}$ was made simultaneously with a D'TA experiment (DTGA) on an independent sample. No detectable change in weight (within $0.001 \mathrm{~g}$ ) was observed during heating and cooling through the various inversion temperatures.

Figure 2 is a postulated stability diagram for the polymorphs of $\mathrm{Bi}_{2} \mathrm{O}_{3}$, based on the data in figure 1 and supported by additional experiments with the low-heat capacity quench furnace, to be discussed later. The ordinate in figure 2 is an undefined measure of stability, for example, free energy of formation or vapor pressure. The metastable melting point of Mon $\mathrm{Bi}_{2} \mathrm{O}_{3}$ is shown at approximately $800{ }^{\circ} \mathrm{C}$, the temperature at which liquid was detected in the high-temperature $x$-ray furnace during rapid heating of the Mon form.

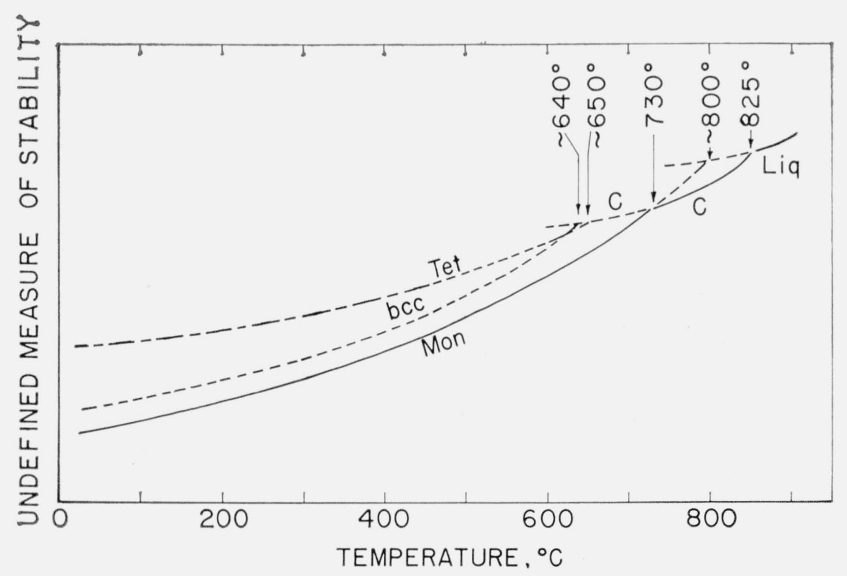

Figure 2. Postulated stability diagram of $\mathrm{Bi}_{2} \mathrm{O}_{3}$. Polymorphs: Mon-monoclinic, $\mathrm{C}-$ cubic, Tet-tetragonal, b.c.c:-body centered cubic, Liq-liquid. 
In the high-temperature $\mathrm{x}$-ray experiments, the Tet phase appeared first on cooling of the $\mathrm{C}$ phase and disappeared last when transformation to the $\mathrm{C}$ form occurred. Therefore, in figure 2 , the metastable $\mathrm{C}$ to Tet inversion is shown at a slightly higher temperature than the metastable $\mathrm{C}$ to b.c.c. inversion. However, considerable overlapping of the two forms occurred, indicating that the two inversion temperatures are near to each other. Below about $640{ }^{\circ} \mathrm{C}$ the b.c.c. phase is shown as more stable than the tetragonal phase, because only the former could be preserved to room temperature by supercooling from high temperatures.

Figure 3 shows a plot of pseudocell dimensions of the various polymorphs of $\mathrm{Bi}_{2} \mathrm{O}_{3}$ versus temperature. The data were obtained by use of the high-temperature x-ray furnace. For comparison purposes, the cell dimensions were reduced to correspond to a pseudounit cell volume for two molecules of $\mathrm{Bi}_{2} \mathrm{O}_{3}$, according to the arbitrary manner given in the caption of figure 3 . The coefficient $\alpha$ of linear thermal expansion for each cell direction was calculated on the original unit cell data by applying least squares to the several sets of data. The cell dimension data were obtained for relatively low $2 \theta$ values (below $\left.50^{\circ}\right)$; and, consequently, the accuracy of the thermal expansion values is estimated to be in the order of $\pm 0.2 \times 10^{-5}$.

The pseudo-orthorhombic (Mon) form showed low linear thermal expansion coefficients, namely, 0.5 $\times 10^{-5}, 1.3 \times 10^{-5}$, and $1.5 \times 10^{-5} \AA / \AA / \mathrm{deg}$ for the $a, b$, and $c$ directions, respectively. The average of these three $\mathrm{x}$-ray determined values is $1.1 \times 10^{-5} / \mathrm{deg}$, in fair agreement with the values reported by Gattow and Schröder [10], using a dilatometric method. Their values ranged from $1.22 \times 10^{-5} / \mathrm{deg}$ at 100 to $200{ }^{\circ} \mathrm{C}$ to $1.48 \times 10^{-5} / \mathrm{deg}$ at 575 to $675^{\circ} \mathrm{C}$. The coefficient of linear thermal expansion found in the present work for the $\mathrm{C}$ form, $2.4 \times 10^{-5} / \mathrm{deg}$, is

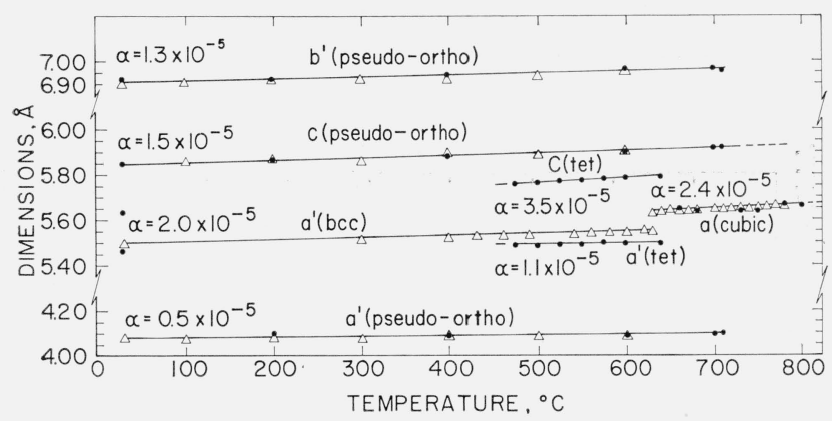

Figure 3. Pseudocell dimensions (based on $\mathrm{Z}=2$ ) of the polymorphs of $\mathrm{Bi}_{2} \mathrm{O}_{3}$ versus temperature.

Cell dimensions have been reduced to correspond to $Z=2 \mathrm{Bi}_{2} \mathrm{O}_{3}$, in the following arbitrary manner:

pseudo-orthorhombic-monoclinic polymorph

$a^{\prime}(Z=2)=(1 / 2) a(Z=8), b^{\prime}(Z=2)=(1 / 2) b(Z=8), c(Z=2)=c(Z=8)$.

Cubic-cubic polymorph

$a(Z=2)=a(Z=2)$

et-tetragonal polymorph

$a^{\prime}(Z=2)=(1 / 2) a(Z=8), c(Z=2)=c(Z=8)$.

b.c.c.-body-centered cubic polymorph

$a^{\prime}(Z=2)=\sqrt[3]{2 / 13} \quad(Z=13)$.

$\alpha=$ coefficient of linear thermal expansion, calculated by method of least squares on original data.

- from certified reagent grade (ACS) $\mathrm{Bi}_{2} \mathrm{O}_{3}$.

-from "Spec. pure" grade $\mathrm{Bi}_{2} \mathrm{O}_{3}$. almost half that reported by Gattow and Schröder, $4.36 \times 10^{-5} / \mathrm{deg}$. The $c$ axis for Tet $\mathrm{Bi}_{2} \mathrm{O}_{3}$ showed the largest coefficient of linear thermal expansion, $3.5 \times 10^{-5} / \mathrm{deg}$. Based on volume expansion, however, the $\mathrm{C}$ form would show the greatest coefficient of expansion $\left(7.2 \times 10^{-5} / \mathrm{deg}\right)$, and the Mon form, the lowest expansion $\left(3.3 \times 10^{-5} / \mathrm{deg}\right)$.

Because the different polymorphs of $\mathrm{Bi}_{2} \mathrm{O}_{3}$ do not have the same number of molecules per unit cell, a comparison of unit cell dimensions is not as instructive as a volume comparison. Figure 4 shows a plot of temperature versus the volumes per molecule of the different polymorphs of $\mathrm{Bi}_{2} \mathrm{O}_{3}$. The percentage expansion or contraction at a phase transition is also given.

It may be seen that the Mon phase shows a large expansion, 6.9 percent, when transforming to the $\mathrm{C}$ phase at $730{ }^{\circ} \mathrm{C}$. Gattow and Schröder reported a volume expansion at the transition temperature of $4.11 \pm 0.06$ percent. Thus the present authors obtained a higher percentage of volume expansion at the Mon to $\mathrm{C}$ transition temperature and a lower coefficient of linear thermal expansion for the cubic form, than did Gattow and Schröder. Gattow and Schröder used a relatively fast heating rate of $7 \%$ min, but the Mon to $\mathrm{C}$ transition is not instantaneous

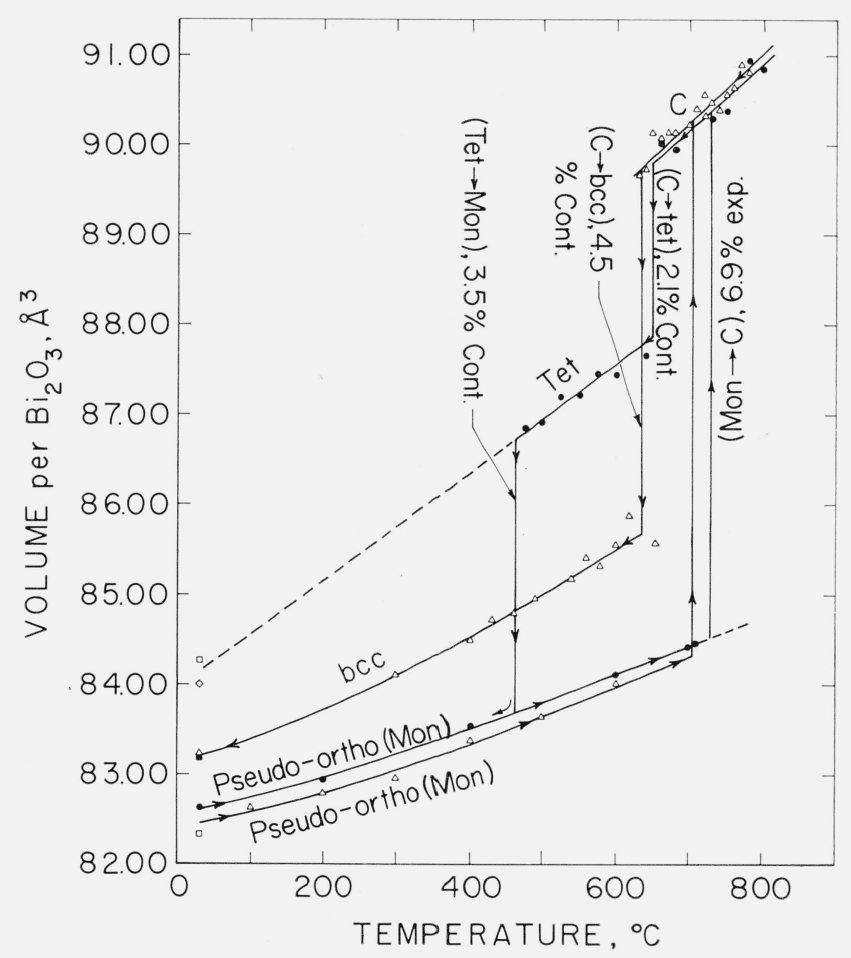

Figure 4. Volume per molecule versus temperature for the polymorphs of $\mathrm{Bi}_{2} \mathrm{O}_{3}$.

(Calculated from the unit cell dimensions obtained with the high-temperature -ray diffractometer furnace).

Polymorphs: Pseudo-orthorhombic (Mon)-monoclinic, C-cubic, Tettetragonal, b.c.c.-body-centered cubic.

$\%$ exp.-percentage expansion at transition.

cont.- percentage contraction at transition.

-from certified reagent grade (ACS) $\mathrm{Bi}_{2} \mathrm{O}_{3}$.

-from "spec pure" grade $\mathrm{Bi}_{2} \mathrm{O}_{3}$

-from decomposition of bismutite.

data taken from Sillén [5].

- data taken from Schumb and Rittner [6]. 
and occurs over a temperature range. Gattow and Schröder's results may be explained on the basis that in their experiments all of the Mon form did not transform at the inversion temperature but continued to transform during heating of the $\mathrm{C}$ phase. Such a situation would lead to an apparently low Mon to $\mathrm{C}$ expansion and an apparently high thermal expansion of the $\mathrm{C}$ phase.

The $\mathrm{C}$ to Tet transition involves a relatively small contraction, 2.1 percent, indicating the similarity in unit cell volumes of the two forms. The contraction in the transition from the $\mathrm{C}$ to b.c.c. is 4.5 percent. It is seen that the temperature dependence of the volume per $\mathrm{Bi}_{2} \mathrm{O}_{3}$ varies for the polymorphs and that the room temperature volume differences are considerably less than at higher temperatures.

\subsection{Low-Heat Capacity Furnace Results}

The $\mathrm{C}$ form of $\mathrm{Bi}_{2} \mathrm{O}_{3}$ cannot be "quenched" at room temperature. In previous phase equilibrium studies by the present investigators [1, 2] only the Mon phase was obtained in pure $\mathrm{Bi}_{2} \mathrm{O}_{3}$ by quenching samples in sealed platinum tubes from all temperatures up to $100{ }^{\circ} \mathrm{C}$ above the melting point of $\mathrm{Bi}_{2} \mathrm{O}_{3}$. The stability diagram (fig. 2), however, indicated a method whereby the metastable phases might be obtained at room temperature, as follows: (a) Heating a sample in a sealed platinum tube to a temperature at which it would be definitely all cubic (above about $775{ }^{\circ} \mathrm{C}$ ) or liquid. (b) Slow cooling of the sample to about $625{ }^{\circ} \mathrm{C}$, with the possibility that the $\mathrm{C}$ phase would be supercooled below $730{ }^{\circ} \mathrm{C}$ and would transform to one of the metastable phases. (c) Quenching the metastable phase existing at temperature.

Accordingly, a number of experiments were performed with the low heat capacity furnace in which temperatures and rates of cooling were varied. Identification was by means of the x-ray powder diffraction method applied to the quenched samples.
The essential results are summarized as follows: (a) Pure b.c.c. $\mathrm{Bi}_{2} \mathrm{O}_{3}$ was formed by heating a sample above the liquidus, at $850{ }^{\circ} \mathrm{C}$ for $10 \mathrm{~min}$, cooling to $625^{\circ} \mathrm{C}$ in about $45 \mathrm{~min}$, and continued heating at this temperature for $5 \mathrm{~min}$, before quenching.

(b) Body-centered cubic $\mathrm{Bi}_{2} \mathrm{O}_{3}$ with a trace of Tet $\mathrm{Bi}_{2} \mathrm{O}_{3}$ could be formed by heating a sample below the liquidus, to $775^{\circ} \mathrm{C}$. 'The cooling schedule was similar to that in (a).

(c) Pure b.c.c. $\mathrm{Bi}_{2} \mathrm{O}_{3}$ could be formed readily below the liquidus temperature by a recycling heat treatment, namely, by heating twice to 780 to $785^{\circ} \mathrm{C}$ and cooling twice to about $625^{\circ} \mathrm{C}$, before quenching.

(d) These experiments never yielded a large amount of Tet $\mathrm{Bi}_{2} \mathrm{O}_{3}$. In several cases, however, the Mon phase was found with a trace of the Tet; it seems probable that at temperature the specimens were Tet.

The work of Royen and Swars [8] is related to the problem of forming Tet $\mathrm{Bi}_{2} \mathrm{O}_{3}$ from pure bismuth oxide. They formed some Tet $\mathrm{Bi}_{2} \mathrm{O}_{3}$ by fast quenching of molten $\mathrm{Bi}_{2} \mathrm{O}_{3}$ from temperatures above about $850{ }^{\circ} \mathrm{C}$. Their work was essentially substantiated in the present investigation, by quenching specimens enclosed in platinum foil envelopes from temperatures of $930{ }^{\circ} \mathrm{C}\left(5 \mathrm{~min}\right.$ heating period) and $980{ }^{\circ} \mathrm{C}$ (1 min heating period). It may be noted that although the Tet phase was present in appreciable amounts, the major phase consisted of $\mathrm{Mon} \mathrm{Bi}_{2} \mathrm{O}_{3}$. Quenching from the higher temperature did not yield an appreciable higher percentage of the Tet phase. However, samples contained in sealed platinum tubes and quenched from the same temperatures showed only Mon $\mathrm{Bi}_{2} \mathrm{O}_{3}$.

\subsection{Aging Experiments on $\mathrm{Bi}_{2} \mathrm{O}_{3}$}

During the course of the work, an aging effect on $\mathrm{Bi}_{2} \mathrm{O}_{3}$ was discovered. Material from a freshly opened bottle of $\mathrm{Bi}_{2} \mathrm{O}_{3}$ gave an x-ray powder pattern

TABLE 2. Aging experiments on $\mathrm{Bi}_{2} \mathrm{O}_{3}$

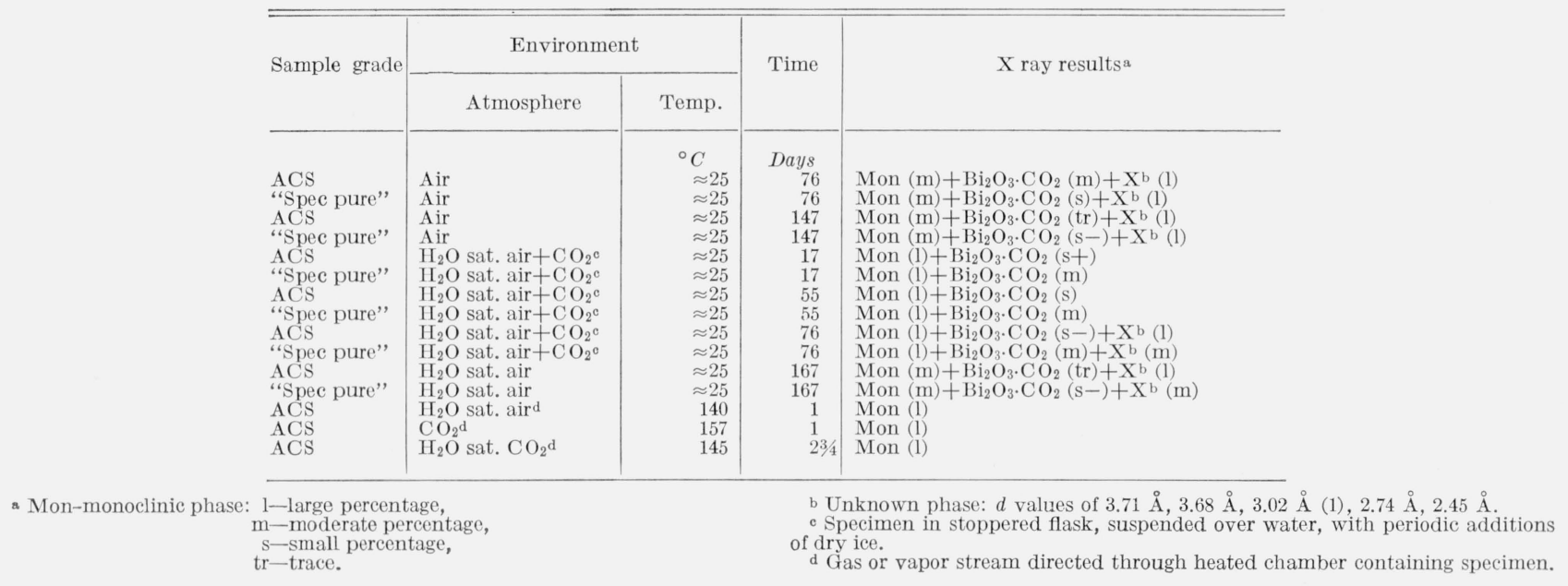


for pure Mon $\mathrm{Bi}_{2} \mathrm{O}_{3}$. About six months later, however, material from the same bottle, which had not been desiccated, showed the prominent diffraction peaks corresponding to bismutite $\left(\mathrm{Bi}_{2} \mathrm{O}_{3} \cdot \mathrm{CO}_{2}\right)$. The effect of the bismutite formation seemed to be a tendency toward lowering of the temperature of the Mon to $\mathrm{C}$ inversion to about $715^{\circ} \mathrm{C}$ and also toward increasing the probability of forming the b.c.c. phase during supercooling of cubic $\mathrm{Bi}_{2} \mathrm{O}_{3}$. This effect may be seen in figure 4 , for a sample of spectrographic purity and offers a possible explanation for the lower inversion temperature reported by previous investiga- tors (see table 1). It should be emphasized, however, that the b.c.c. phase could be formed from pure material, as discussed previously under 4.1 and 4.2 , above.

This chance discovery of an aging effect led to a number of experiments (summarized in table 2 ) in an attempt to accelerate the process. Experiments in which pure $\mathrm{Bi}_{2} \mathrm{O}_{3}$ was suspended over water in a stoppered flask and to which additions of dry ice were made periodically produced bismutite in small to moderate amounts, after 17 days. At the end of 55 days there was no increase in amount of bis-

TABLE 3. Thermal decomposition experiments on bismuth compounds

\begin{tabular}{|c|c|c|c|c|c|}
\hline \multirow[b]{2}{*}{ Name } & \multirow{2}{*}{ 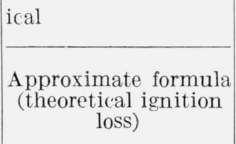 } & \multicolumn{2}{|c|}{ Heat schedule } & \multirow{2}{*}{$\begin{array}{c}\text { Total } \\
\text { ignition } \\
\text { Loss }\end{array}$} & \multirow{2}{*}{$\mathrm{X}$ ray results a } \\
\hline & & Temp. & Time & & \\
\hline Bismutite (U.S.P.) & $\begin{array}{c}\mathrm{Bi}_{2} \mathrm{O}_{3} \cdot \mathrm{CO}_{2} \\
(8.63 \%)\end{array}$ & $\begin{array}{l}{ }^{\circ} C \\
390 \\
390 \\
490 \\
800\end{array}$ & $\begin{array}{r}h r \\
1.5 \\
66 \\
1.5 \\
1 \mathrm{~b}\end{array}$ & $\begin{array}{l}\text { 8. } 08 \\
\text { 8. } 65 \\
\text { 8. }: 5 \\
\text { 8. } 90\end{array}$ & $\begin{array}{l}\text { Tet } \mathrm{Bi}_{2} \mathrm{O}_{3} \\
\text { Tet } \mathrm{Bi}_{2} \mathrm{O}_{3} a-10.9 \AA, c-5.62 \AA \\
\mathrm{Mon} \mathrm{Bi}_{3} \mathrm{O}_{3} \\
\text { b.c.c. } \mathrm{Bi}_{2} \mathrm{O}_{3}+\text { ? (tr) }\end{array}$ \\
\hline Bismutite (U.S.P.) & $\begin{array}{l}\mathrm{Bi}_{2} \mathrm{O}_{3} \cdot \mathrm{CO}_{2} \\
(8.63 \%)\end{array}$ & $\begin{array}{l}200 \\
300 \\
350 \\
400 \\
800 \\
775\end{array}$ & $\begin{array}{c}16 \\
18 \\
4 \\
18 \\
14 \mathrm{~b} \\
2\end{array}$ & $\begin{array}{l}0.29 \\
1.05 \\
5.47 \\
9.08\end{array}$ & $\begin{array}{l}\mathrm{Bi}_{2} \mathrm{O}_{3} \cdot \mathrm{CO}_{2} \\
\mathrm{Bi}_{2} \mathrm{O}_{3} \cdot \mathrm{CO}_{2} \\
\mathrm{Tet} \mathrm{Bi}_{2} \mathrm{O}_{3}(\mathrm{I})+\mathrm{Bi}_{2} \mathrm{O}_{3} \cdot \mathrm{CO}_{2} \\
\text { Tet } \mathrm{Bi}_{2} \mathrm{O}_{3} \\
\text { b.c.c. } \mathrm{Bi}_{2} \mathrm{O}_{3} \\
\text { Mon } \mathrm{Bi}_{2} \mathrm{O}_{3}\end{array}$ \\
\hline $\begin{array}{l}\text { Bismuth subsalicylate } \\
\text { (powder, U.S.P.) }\end{array}$ & $\begin{array}{l}\mathrm{Bi}\left(\mathrm{C}_{7} \mathrm{H}_{5} \mathrm{O}_{3}\right)_{3} \mathrm{Bi}_{2} \mathrm{O}_{3} \\
(35.6 \%)\end{array}$ & $\begin{array}{l}137 \\
200 \\
300 \\
400 \\
450 \\
500\end{array}$ & $\begin{array}{l}16 \\
16 \\
16 \\
16 \\
16 \\
16\end{array}$ & $\begin{array}{l}0.06 \\
.42 \\
35.0 \\
35.54 \\
35.57 \\
35.57\end{array}$ & $\begin{array}{l}\text { Bismuth subsalicylate (?) } \\
\text { Subsalicylate (?)+unknown } \\
\text { Tet } \mathrm{Bi}_{2} \mathrm{O}_{3} \\
\text { Mon } \mathrm{Bi}_{2} \mathrm{O}_{3} \\
\text { Mon } \mathrm{Bi}_{2} \mathrm{O}_{3}\end{array}$ \\
\hline $\begin{array}{l}\text { Bismuth subgallate } \\
\text { (powder) }\end{array}$ & $\begin{array}{l}\mathrm{Bi} \underset{(43.4 \%)}{(\mathrm{OH})_{2} \mathrm{C}_{7} \mathrm{H}_{5} \mathrm{OH}} \\
\end{array}$ & $\begin{array}{l}137 \\
200 \\
300 \\
400 \\
450 \\
500\end{array}$ & $\begin{array}{l}16 \\
16 \\
16 \\
16 \\
16 \\
16\end{array}$ & $\begin{array}{l}10.10 \\
14.02 \\
45.71 \\
45.91 \\
45.92 \\
45.92\end{array}$ & $\begin{array}{l}\text { Bismuth subgallate (?)॰ } \\
\text { Unknown } \\
\text { Tet } \mathrm{Bi}_{2} \mathrm{O}_{3} \\
\text { Mon } \mathrm{Bi}_{2} \mathrm{O}_{3} \\
\text { Mon } \mathrm{Bi}_{2} \mathrm{O}_{3}\end{array}$ \\
\hline Bismuth hydroxided & $\begin{array}{r}\mathrm{Bi}(\mathrm{OH})_{3} \\
(10.4 \%)\end{array}$ & $\begin{array}{l}137 \\
200 \\
300 \\
400 \\
450 \\
500 \\
600 \\
700\end{array}$ & $\begin{array}{r}16 \\
16 \\
16 \\
16 \\
16 \\
16 \\
2 \\
18\end{array}$ & $\begin{array}{l}0.13 \\
.28 \\
1.13 \\
8.18 \\
8.42 \\
8.46 \\
8.50 \\
8.50\end{array}$ & 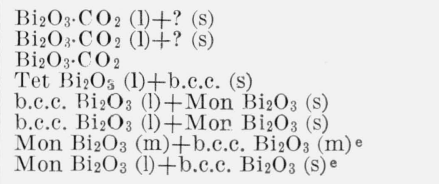 \\
\hline $\begin{array}{l}\text { Bismuth nitrate } \\
\text { (crystals, ACS) }\end{array}$ & $\begin{array}{c}\mathrm{Bi}\left(\mathrm{NO}_{3}\right)_{3} \cdot 5 \mathrm{H}_{2} \mathrm{O} \\
(52.0 \%)\end{array}$ & $\begin{array}{l}137 \\
200 \\
300 \\
400 \\
450 \\
500 \\
800^{\text {f }}\end{array}$ & $\begin{array}{l}16 \\
16 \\
16 \\
16 \\
16 \\
16\end{array}$ & $\begin{array}{l}37.50 \\
39.58 \\
45.38 \\
49.60 \\
51.44 \\
51.44\end{array}$ & $\begin{array}{l}\text { Unknown } \\
\text { Unknown } \\
\text { Amorphous (l)+Unknown (m) } \\
\text { Unknown }(\mathrm{l})+\text { Tet } \mathrm{Bi}_{2} \mathrm{O}_{3}(\mathrm{~m}) \\
{\mathrm{Mon} \mathrm{Bi}_{2} \mathrm{O}_{3}}^{\mathrm{Mon} \mathrm{Bi}_{3}} \\
\text { b.c.c. } \mathrm{Bi}_{2} \mathrm{O}_{3}+\text { ? (tr) }\end{array}$ \\
\hline $\begin{array}{l}\text { Bismuth subnitrate } \\
\text { (powder) }\end{array}$ & $\begin{array}{l}\mathrm{Bi}(\mathrm{OH})_{2} \mathrm{NO}_{3} \\
(23.6 \%)\end{array}$ & $\begin{array}{l}137 \\
200 \\
300 \\
400 \\
450 \\
\\
500\end{array}$ & $\begin{array}{l}16 \\
16 \\
16 \\
16 \\
16 \\
16\end{array}$ & $\begin{array}{r}\text { 2. } 95 \\
4.44 \\
10.81 \\
16.52 \\
19.36 \\
20.25\end{array}$ & 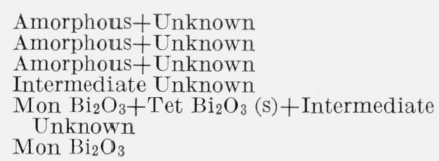 \\
\hline $\begin{array}{l}\text { Bismuth } \\
\text { oxyhydroxide } \mathrm{g}\end{array}$ & $\begin{array}{c}\mathrm{BiO}(\mathrm{OH}) \\
(3.72 \%)\end{array}$ & $\begin{array}{l}135 \\
200 \\
250 \\
300 \\
350 \\
400 \\
450 \\
500 \\
550\end{array}$ & $\begin{array}{r}16 \\
16 \\
16 \\
17 \\
7 \\
16 \\
7 \\
16 \\
16\end{array}$ & $\begin{array}{l}.35 \\
.95 \\
1.57 \\
1.71 \\
1.74 \\
2.77 \\
5.48 \\
5.62 \\
5.62\end{array}$ & 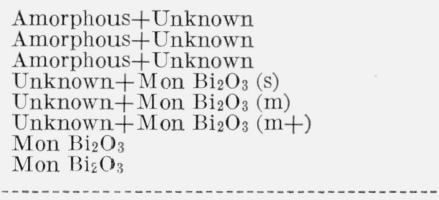 \\
\hline
\end{tabular}

a Polymorphs: Mon-monoclinic, Tet-tetragonal, b.c.c.-body-centered cubic. Percentages: l-large, m-moderate, s-small, tr-trace.

b Platinum crucible containing specimen removed from furnace at temperature and immediately chilled by dipping into ice water. (Water did not touch speci-

o Poorly crystalline. d Commercially obtained preparation, essentially bismutite by x-ray analysis. e $d$ values show shift, indicating smaller unit cell.

$\mathrm{X}$ ray analysis after a DTA experiment.

g Prepared in National Bureau of Standards Laboratory by Johan H. deGroot by adding bismuth nitrate to boiling 20 percent $\mathrm{NaOH}$ soln., in $\mathrm{Pt}$ dish. Material dried at $60^{\circ} \mathrm{C}$ for $17 \mathrm{hr}$, then at $85^{\circ} \mathrm{C}$ for $65 \mathrm{hr}$. 
mutite formed. After 76 days, samples exposed to water vapor and $\mathrm{CO}_{2}$ or to air at room temperature showed a large amount of an unidentified phase (X in table 2). With continued exposure the unidentified phase, in both experiments, increased at the expense of the bismutite and Mon phases. Attempts to rapidly accelerate the formation of bismutite or the unknown phase by passing over the heated sample a stream of (1) $\mathrm{CO}_{2}$ gas, (2) $\mathrm{CO}_{2}$ saturated water vapor, or (3) water saturated air, were unsuccessful (see last 3 experiments of table 2). The aging experiments demonstrate the fact that $\mathrm{Bi}_{2} \mathrm{O}_{3}$ is reactive under atmospheric conditions and must be tightly sealed and desiccated to avoid compositional changes.

\subsection{Thermal Decomposition Experiments}

The discovery of bismutite $\left(\mathrm{Bi}_{2} \mathrm{O}_{3} \cdot \mathrm{CO}_{2}\right)$ in aged bismuth oxide samples led directly to thermal decomposition studies of bismutite and other bismuth containing organic compounds (see table 3). Approximately $1 \mathrm{~g}$ samples were accurately weighed into 30 $\mathrm{ml}$ platinum crucibles, heated in an electric resistance furnace at successively higher temperatures, and cooled in air. Ignition losses and x-ray powder diffraction patterns of the samples were obtained for the successive heat treatments.

It is seen from table 3 that bismutite heated at $390{ }^{\circ} \mathrm{C}$ for $66 \mathrm{hr}$ or at $400{ }^{\circ} \mathrm{C}$ for $18 \mathrm{hr}$ produced pure Tet $\mathrm{Bi}_{2} \mathrm{O}_{3}$. Within the limit of accuracy of the weight loss measurements, it appears that all of the $\mathrm{CO}_{2}$ was driven off. At $490{ }^{\circ} \mathrm{C}$, the Tet $\mathrm{Bi}_{2} \mathrm{O}_{3}$ was transformed to the stable Mon phase. Rapid cooling of a sample from $800^{\circ} \mathrm{C}$, by immersion of the bottom of the crucible in cold water, produced the b.c.c. phase.

Bismuth subsalicylate and bismuth subgallate when heated at $300{ }^{\circ} \mathrm{C}$ for $16 \mathrm{hr}$ also yielded pure Tet $\mathrm{Bi}_{2} \mathrm{O}_{3}$. At the $400{ }^{\circ} \mathrm{C}$ heat treatment, the Tet phase was converted to the Mon phase.

The bismuth hydroxide sample, which was shown by $\mathrm{x}$-ray analysis to be mainly bismutite, yielded three forms of $\mathrm{Bi}_{2} \mathrm{O}_{3}$ during decomposition. A large amount of the tetragonal phase was formed at $400{ }^{\circ} \mathrm{C}$. At 450 and $500{ }^{\circ} \mathrm{C}$, the Tet phase had disappeared, and the sample contained a large amount of the b.c.c. phase plus a small amount of the Mon phase. This transition supports the previously drawn conclusion that, at lower temperatures, the b.c.c. phase is more stable than the Tet phase. The $600{ }^{\circ} \mathrm{C}$ heat treatment produced an increasing amount of the Mon phase, at the expense of the b.c.c. phase. The remaining b.c.c. phase showed a shift in diffraction peaks corresponding to smaller $d$ values. This shift would be consistent with a decrease in unit cell size, when certain foreign ions are added to pure $\mathrm{Bi}_{2} \mathrm{O}_{3}$, as will be discussed in part II.

Bismuth nitrate and bismuth subnitrate yielded some Tet $\mathrm{Bi}_{2} \mathrm{O}_{3}$ during decomposition, but never in major amount. By the end of the $500{ }^{\circ} \mathrm{C}$ heat treatment the samples were all $\mathrm{Mon} \mathrm{Bi}_{2} \mathrm{O}_{3}$. Bismuth oxyhydroxide transformed directly from the amorphous state to the Mon form of $\mathrm{Bi}_{2} \mathrm{O}_{3}$.

These experiments indicate that the decomposition of organic bismuth compounds at temperatures below $400{ }^{\circ} \mathrm{C}$ tend to produce the tetragonal form of $\mathrm{Bi}_{2} \mathrm{O}_{3}$. If, however, higher temperatures are required for complete decomposition, then the stable Mon $\mathrm{Bi}_{2} \mathrm{O}_{3}$ phase is formed.

\section{Summary}

By means of DTA and high-temperature x-ray studies it has been shown that pure bismuth oxide possesses two stable and two metastable polymorphs. A stable reversible transition between the low temperature Mon and the high temperature cubic form occurs at $730 \pm 5{ }^{\circ} \mathrm{C}$. The Mon to cubic transition is accompanied by a volume expansion of 6.9 percent. The cubic form shows the greatest coefficient of volume expansion $\left(7.2 \times 10^{-5} / \mathrm{deg}\right)$. The melting point of the cubic phase is $825 \pm 5{ }^{\circ} \mathrm{C}$. Supercooling of the cubic form below the $730{ }^{\circ} \mathrm{C}$ Mon transition produces either the metastable tet form at $650^{\circ} \mathrm{C}$ or the metastable b.c.c. form at about $640{ }^{\circ} \mathrm{C}$. The results are given in table 1 . Whereas by fast cooling, the b.c.c. phase can be preserved to room temperature, the tetragonal phase transforms to the stable Mon phase between 550 and $450{ }^{\circ} \mathrm{C}$. Tetragonal bismuth oxide, however, can be formed readily by the decomposition of bismutite at $400{ }^{\circ} \mathrm{C}$ for $18 \mathrm{hr}$ or by the decomposition of bismuth subgallate and bismuth subsalicylate at $300{ }^{\circ} \mathrm{C}$ for $16 \mathrm{hr}$. The Tet bismuth oxide so formed is preserved at room temperature. Bismuth oxide is subject to an aging effect in air and transforms partially to bismutite. With continued exposure an unidentified phase forms.

\section{References}

[1] E. M. Levin and C. L. McDaniel, J. Am. Ceram. Soc. 45 [8] 355-360 (1962).

[2] R. S. Roth and J. L. Waring, J. Res. NBS 66A (Phys. and Chem.) No. 6, 451-463' (1962).

[3] W. Guertler, Z. Anorg. Chem. 37, 222-224 (1903).

[4] L. Belladen, Gazz. Chim. Ital. 52II, 160-164 (1922).

[5] L. G. Sillén, Arkiv Kemi, Mineralogi och Geologi 12A [18] 1-13 (1937).

[6] W. C. Schumb and E. S. Rittner, J. Am. Chem. Soc. 65, $1055-1060$ (1943)

[7] B. Aurivillius and L. G. Sillén, Nature 155, No. 3932, 305-306 (1945).

[8] P. Royen and K. Swars, Angew. Chem, 69 [24] 779 (1957).

[9] I. N. Belyaev and N. P. Smolyaninov, Zhur. Neorg. Khimi. VII [5] 1126-1131 (1962).

[10] G. Gattow and H. Schröder, Zeit. Anorg. Allgem. Chem. 318 [3-4] 176-189 (1962).

[11] F. A. Mauer and L. H. Bolz, WADC (Wright Air Develop. Center) Tech. Rept., No. 55-473 (December 1955).

[12] E. M. Levin and F. A. Mauer, J. Am. Ceram. Soc. 46 [1] 59-60 (1963).

(Paper 68A2-268) 